\title{
Educating Muslim Malay Society In Confronting The Phenomenon Of Fabricated Hadith Propagation
}

\section{Firdaus Khairi Abdul Kadir ${ }^{a}$, Muhamad Khairul Zakariab ${ }^{b}$ Rahimah Embong ${ }^{c^{*}}$, Noorsafuan Che Noh ${ }^{d}$, Abdul Qahhar Ibrahim ${ }^{\mathrm{e}}$, Nik Muniyati Nik Din ${ }^{\mathrm{f}}$}

${ }^{a}$ Universiti Malaysia Terengganu (UMT), Terengganu, Malaysia.

bUniversiti Malaysia Terengganu (UMT), Terengganu, Malaysia.

${ }^{c *}$ Faculty of Islamic Contemporary Studies, Universiti Sultan Zainal Abidin, Malaysia.

Email: rahimahembong@unisza.edu.my

${ }^{\mathrm{d}}$ Faculty of Islamic Contemporary Studies, Universiti Sultan Zainal Abidin, Malaysia.

${ }^{\mathrm{e}}$ Faculty of Islamic Contemporary Studies, Universiti Sultan Zainal Abidin, Malaysia.

${ }_{\mathrm{f}}^{\mathrm{f}}$ Academy of Contemporary Islamic Studies, Universiti Teknologi MARA Kelantan Branch, Malaysia.

Article History: Received: 11 January 2021; Accepted: 27 February 2021; Published online: 5 April 2021

\begin{abstract}
The two major sources of the religion of Islam is the Quran and Hadith. Devoid of both, Muslims will certainly stray from the path of truth. Via the promptness of information technology nowadays, the two sources of commandment turn out to be easily referenced and studied. Nonetheless, it is worrying that with the distance of the present day to the time of the Messenger of Allah, the source of the law in particular al-Hadith entails to be verified before dissemination. Currently, many queries about the hadith arise, due to the existence of those who have taken the opportunity to boost their sales or introduce certain novel act of worships that are alleged to originate from the Messenger of Allah. However, when reexamined by the contemporary scholar of hadith, it is found that the hadiths were either false or extremely feeble. In reality, what is even more unsettling is the blunder originated from the religious preacher whom involved in the spreading of false hadiths in their lectures. So much so that the public is often muddled about the legitimacy of their religious practices. With that in mind, studies on the legality of legal sources such as hadiths need to be deliberated and researched. Hence, the study was conducted to recommend pertinent resolutions to ensure that Muslims; especially in the end times, to ensure their devotion are based on Quran and al-Hadith. The methodology of the study take on archival research by scrutinizing the renowned books of evidence and eminent contemporary writings in the field of study to ensure that this study is more reliable and capable to answer existing problems. In addition, this study also employed qualitative methods via interviews with prominent leaders in the field of study along with the observations of the researcher especially in the course of this study. Upon the completion of the research, there are several findings that indicate that the phenomenon ensued due to the failure of Muslims to preserve the authenticity of the hadith by inattentively allowing some practices to be performed without any reference to the established manuscript of hadiths, resulting in some practices being made based on false hadiths.
\end{abstract}

Keywords: Hadith, Fake Hadith, Malay Community.

\section{Introduction}

Islam is a comprehensive religion and covers all aspects of human life. Islam has been in line with the will of the times, since the time of Prophet Adam AS to the end of time. When the Messenger of Allah (May peace be upon him) was sent to be the last Prophet, then the fulfillment of the Islamic law imposed by Allah was complete and accomplished. This is stated by Allah in surah al-Maidah verse 3,

\section{Meaning;}

This day I have perfected for you your religion and completed My favor upon you and have approved for you Islam as religion. But whoever is forced by severe hunger with no inclination to sin - then indeed, Allah is Forgiving and Merciful.

In the meantime, the Messenger of Allah (May peace be upon him) also commanded during the Hajjatul Wada' (farewell pilgrimage) to all Muslims, according to his word;

Meaning;

I have left two matters with you. As long as you hold to them, you will not go the wrong way. They are the Book of Allah and the Sunna of His Prophet

Hadith narrated by Imam Malik in the book of Muata' 
After the passing of the Messenger of Allah, Islam continued to propagate through the ages based on two main sources namely the Quran and the Sunnah. The religious source of the Quran remains preserved to this day in line with God's promise to preserve its authenticity. This is stated in His word in surah al-Hijr, verse 9 ,

Meaning: "Indeed, it is We who sent down the Qur'an and indeed, We will be its guardian".

Nevertheless, what is upsetting is the position of al-Hadith which is fundamental to the retention of al-Sunnah. Therefore, scholars' hadiths since the time of the Tabieen such as Imam Bukhari, Muslim, Ahmad bin Hanbal and many others are very dedicated to classifying the dignity of the hadith to ensure that the authenticity of the hadith is also preserved. As a result, the emergence of popular terms in the study of hadith such as Hadith Sahih, Hadith Hasan, Hadith Daif and Hadith Maudhu' or false. So does the terms for the narrator of hadiths such as thiqah (reliable), dhabit (strength of memorization) and so on.

\section{Literature Review}

Conferring to Faisal Ahmad Shah (2016) the phenomenon of spreading false hadiths is swelling nowadays, as the method of propagation has become easier and faster through the use of modern technology. The main medium of dissemination is through social media such as Facebook, Whatsapps and similar things. The medium has now become a threat to the community, when exploited as a channel for the dissemination of false hadiths without scrutiny. According to him, most of the false hadiths were distributed without the original Arabic source. The spreader of hadith merely using the Malay language and that made it difficult for the scholar in the field of hadith to trace the original source. The authenticity of the original source may or may not exist, but there is still a need to reexamine whether the source of the original hadith is valid or not.

Abdul Hayei (2008) stated in his book entitled "Hadith Mawdu' History and How to Know It," that the hadith that is fabricated or falsified is divided into two. First, false or personal words, then it is treated as the words or words of the Prophet. Second, false words that are not the words of the Prophet (SAW), such as the words of companions, tabi'in, hukama', sufi, or others. Or the narration originate from the source of Isra'iliyyat, then it is linked to the Prophet, to gain the trust of the community. According Jawiah Dakir (2014) from the Faculty of Islamic Studies in her inaugural lecture entitled, "The existence of al-Mawdu in Malay Society", there are almost $34.42 \%$ mawdu' hadith and dhaif hadith that is often used by the Malays in Malaysia. The findings of her study is based on 825 popular hadiths among the Malay community, of which 285 are mawdu' hadith.

According Rozaimi Ramle (2016) there are many popular fabricated hadiths circulating in the Malay community. The hadiths have been around for so long and have partially been upheld as vital core of believe within the Malay community. Among the examples of false hadiths that linger in the Malay community is the hadith that stated not go to heaven for those who do not like kids, hadith about kissing the children will raise their level in heaven and hadith about the advantages of breast-feeding mother and taking care of children. He also stated that most of the hadiths describing the events of Israk and Mikraj were inadequate (daif) and should not be dispersed. However, there are also authentic hadiths. Therefore, it is preferable for the religious scholars who are responsible for giving lectures on the events of Isra' and Mikraj refers to the status of the hadith before delivering it.

Correspondingly, the stories of earlier prophets such as Prophet Ayub, Prophet Daud, Prophet Syuib, Prophet Khair and other prophets were largely not based on authentic hadiths narration. These stories are largely derived from Israeli (Israiliyyat) storytelling. This is what Basri Ibrahim (2006) states in his book The Stories of Prophets That Could Not Be Utilized as Argument. He also elucidated the phenomena of Muslims conception and understanding that are very much tied to the stories of the Prophet Muhammad himself with the association of false hadiths or hadiths that are too weak such as munkar hadiths, matruk and so on. However, these kind of hadiths are often applied as important subject matter by the Muslim clergy in decreeing the messenges from Prophet Muhammad.

Consecutively, Abdul Razak Muthalib (2016) also published a book on the phenomenon of the emergence of false and weak hadiths in his book entitled 40 Common False and Weak Hadiths. In this book, the author describes some hadiths that have been upheld by the Malay community regardless of fabricated or poor status, among them is related to the false hadith about the children born out of wedlock can not go to heaven, and many more. The book also encompasses some particular practices that are not based on the authentic hadith, but mentioned with particular prominence (fadhilat) that linked with the practice to encourage the public to do so. 
Conversely, in Islam any form of fadhilat must be based on the Quran or hadith of the Prophet which is evidently valid.

\section{Research Methodology}

In this study, the methodology applied is content analysis which obtained through the study of ancient and modern scriptures. This research methodology was chosen because the legal debate on Islam requires research based on content analysis or library research. In addition, the qualitative method was also utilized by interviewing a key informant who was directly involved in the study. Nevertheless, the findings are also supported by content analysis and researcher's observations.

\section{Findings and Discussions}

The findings from this study found that the life and existence of the the society, especially in the end times, was so vulnerable and so exposed to various forms of lying and falsehood that Muslims found it difficult to find the sources with authenticity. Ever since long ago, the Messenger of Allah (May peace be upon him) was aware of this concern. Thus, towards the end of his age, he once told his friends about the conflicts that Muslims would face. The guidance was narrated by a companion named Irbadh bi Sariah as follows,

Meaning;

The Messenger of Allah (May peace be upon him) sent us a reminder, which has touched our hearts and brought tears to our eyes. One of us said, "Say something to us, O Messenger of Allah, (the message) as if it were a farewell warning. What would you like to tell us? The Messenger of Allah (May peace be upon him) said, "Indeed, those who live after me will see many disputes. It is obligatory upon you to obey my sunnah and the sunnah of Khulafa' al-Rasyidin after me, that they will be guided by Allah. Hold on to it (the Sunnah of the Prophet and khulafa 'al-Rasyidin), and bite it (sunnah) with your molars. Beware of new invention in worship, because every new practice is a bid'ah.

Hadith Narated by Abu Daud, Tarmizi, Ibn majah and Ahmad.

As stated by the interviewed key informants, he explained that the hadith shows the Prophet's concern for Muslims after his death. These concerns are essential, especially in relation to the tendency of human beings to upheld practices and act of worship without reference. These reminders and orders are to ensure that Muslims verify and check in advance whatever practices to be performed. To make sure whether is it true to the sunnah of the Prophet or the sunnah of his companions? If a practice occurs without the backing of the syariah, there is huge apprehension that it is disregarded in accordance with the requirements of Islamic law. Therefore, it is best to leave the practice alone. This view is in line with the Messenger's orders and warnings against those who spread false hadiths as His word says;

Meaning; "Ascribing false things to me is not like ascribing false things to anyone else. Whosoever tells a lie against me intentionally then surely let him occupy his seat in Hell-Fire."

Hadith Narrated by Muslim.

Although the Messenger of Allah (May peace be upon him) had warned his people not to lie in his name, the Prophet's pronouncement was ignored by the creators of false hadiths. They have appeared for a long time since the time of Khulafa 'al-Rasyidin. Many scholars of Islamic history hold the conviction that the spread of false hadith began during the slander of Saidina Uthman bin Affan leading to his murder. Afterward, false hadiths continued to spread, causing Muslims to split up into various factions such as Syiah, Khawarij, Murjiah and so on.

At the same time, there are other causes in the tabien era such as the innovation of the hadith to boost the influence of a teacher or for the purpose of appealing the government of the time. As a result of the fabrication of the hadith, the Muslims have been misunderstood, which is a true authentic hadith from the Messenger of Allah and which is a false one.

The spread of false hadiths has taken place throughout the Muslim world, with no exception to the Muslims in the Malay Archipelago (Nusantara). In recent times, after a number of surveys have been conducted, the findings with regard to spreading factors are listed as follows;

1. Spreading false hadiths which comes in the Malay language without the original text in Arabic. The spread of this kind are likely to occur, when the Malay text is easily understood by the Muslims in this 
region and easily deployed with the latest applications like Whatsapps, E-Mail, Facebook and such. Typically for Muslims, when any text is relied on to the Messenger of Allah, without any thought, they continues to spread it to other friends. Conversely, the proper step is to consult the religious scholar first before transmitting it.

2. The tendency of Muslims to earn more rewards when doing something good. There is no denying that there are authentic hadiths on the merits of certain practices such as the fadilat of performing prayers in the Sacred Mosque according to the word of the Messenger of Allah;

Meaning; Prayers in the Masjidil Haram are better than 1000 times in other mosques.

Hadith narrated by Ahmad and Ibnu Majah

However, some irresponsible people have fashioned certain rewards for certain practices to encourage Muslims to do so. Apparently, Muslims need to be aware of this matter and verify every practice that they want to perform.

3. There are some Muslims who have carefree attitude toward the propagation of false hadiths, despite the fact that the fabricated specifics are too extreme. For example, false hadiths related to the benefits of the practice of 10 Muharram. The creator of the false hadith says that Allah will forgive the sins for the past 50 years and the next 50 years. In fact, it will be rewarded 1000 times by Hajj and 1000 times by Umrah and 1000 times the value of martyrs. God will then ask all the animals to pray for their forgiveness. The degree of the allegations are very over the top, but they are still circulated to the public.

\section{Impact of Spreading False Hadith}

During the spread of false hadiths, the foremost apprehension is related to the impact that its spreaders will have, especially on the religious creed (akidah) and religious practical aspects of Muslim community. According to Abdul Razak Muthalib (2016) there are several effects that have been identified in the course of the spread of false hadiths which include,

i. The threat of the Messenger of Allah upon those who created the false hadith would be put in hell as the Prophet said,

Meaning; "Ascribing false things to me is not like ascribing false things to anyone else. Whosoever tells a lie against me intentionally then surely let him occupy his seat in Hell-Fire."

Hadith narrated by Muslim.

ii. Muslims do not have a true understanding of their religion. For example the existence of a false hadith that states that the children born out of wedlock will not enter heaven. This fact clearly contradicts the Quranic surah al-Isra 'verse 15,

Meaning: Whoever is guided is only guided for [the benefit of] his soul. And whoever errs only errs against it. And no bearer of burdens will bear the burden of another. And never would We punish until We sent a messenger.

iii. Encouraging the faith of syirik, while the Islamic faith concentrates heavily on the concept of oneness of Allah (tauhid). This is the case when a false hadith be present that describes the benefits of stone that derived from human reasoning. The impact of the conviction will inspire amulet fans to cling to the lie.

iv. Ruining the image and authority of Muslim figures as the emergence of false hadith insulted Imam Shafie and elevated the prestige of Imam Hanafi. This is evidenced by the dissemination of the false hadith, which means,

"There will be among my people a man called Muhammad bin Idris (Imam Shafie). He harms my people more than Satan. There will be among my people a man called Abu Hanifah. He is a lamp that illuminates my people. "

\section{Overcoming Steps}

In ensuring that the authenticity of Islamic Shari'ah is preserved and endured to the end of the ages, it is recommended that certain steps be taken by all Muslims. 
Firdaus Khairi Abdul Kadir ${ }^{\mathrm{a}}$, Muhamad Khairul Zakaria ${ }^{\mathrm{b}}$, Rahimah Embong ${ }^{\mathrm{c}^{*}}$, Noorsafuan Che Noh ${ }^{\mathrm{d}}$, Abdul Qahhar Ibrahim ${ }^{\mathrm{e}}$, Nik Muniyati Nik $\operatorname{Din}^{\mathrm{f}}$

1. All Muslims should be extra aware of any history or pertinent exemplary associated with the Messenger of Allah. In order to ensure the authenticity of al-Sunnah is preserved, we should refer to the scholars who are skilled and trained in the field of hadith.

2. To the orators, do not be too passionate and take things with carefree attitude in employing hadith particularly that do not have clear status of the authenticity. It is advisable that the speakers should first check the status of the hadith to be recited. It is believed that the hadith may be a false hadith. Indirectly, we are exposed to the slander of spreading a false hadith, which was greatly enraged by the Messenger of Allah.

3. For religious clergy, it is advisable to use notable books that have been acknowledged in regard of the authenticity of the hadith. For that reason, the religious scholar are encouraged to use such highly authentic hadith books such as Sahih Bukhari, Sahih Muslim, Riyadhul Salihin and other wellestablished book of hadiths.

4. Authorities also need to launch the undertaking of translating the well-reviewed (tahqiq) hadith books by hadith experts who have published in Arabic. This proposal is intended to facilitate the speakers to refer to the hadiths which have been reviewed by the scholars in the pertinent field.

5. Social media users such as facebook, Whatsapps, Telegrams and the like, should be careful in transmitting hadiths quotes from accepted messages. Please make sure the originality of the hadith first, before distributing it to your other friends.

\section{Conclusion}

As a conclusion to the issue raised, it is appropriate for all Muslims to be thoughtful and take a serious look at the fundamental issues of our religion. The religious scholars also need to be more serious about securing the authenticity of Islamic Shari'ah to continue in perpetuity. Our failure to maintain the authenticity of the hadiths of the Prophet (SAW), will cause the next generation of Muslims to be exposed to the heresy (bidaah) and superstition (khurafat) which are opposed by the Messenger of Allah. It is hoped that this kind of studies can help Muslims to be more careful when receiving any distribution of hadith, so that we can all survive the defamation of lies (fitnah) in the name of Prophet Muhammad SAW.

\section{Corresponding Author}

Rahimah Embong, PhD. is an Associate Professor at Department of Education, Dakwah \& Islamic Civilization at Faculty of Islamic Contemporary Studies at Universiti Sultan Zainal Abidin (UniSZA), Gong Badak Campus, 21300 Kuala Nerus. Terengganu, Malaysia.

\section{References}

1. Shah, F.A. (2016). The Spread of False Hadith in Mass Media and Social Media: Reality and Challenges. Journal of Hadith INHAD, 6(11), 9-27.

2. Bakar, I.A. (1993). Three Muslim Modernist's Thought of Reason In Islam. Journal of Islamiyyat, 14 $\mathrm{UKM}, 80$.

3. bin Ibrahim, A.F.H, (1999). The Influence of Spirituality in Islamic Society in Malaysia. Yayasan Isalm Terengganu.

4. Sukor, A.H.A. (2008). Mawdu Hadith 'History and Ways to Recognize It. Kuala Lumpur: Department of Islamic Development Malaysia.

5. Muttalib, A.R. (2016). Popular False and Weak Hadith. Selangor, PTS Publishing House.

6. Ibrahim, B. (2006). Stories of Prophets Who Cannot Be Argued. Kuala Lumpur, Darul Nu'man.

7. Kadir, F.K.A. (2010). Bid'ah Dalalah. Kuala Terengganu: Majlis Agama Islam dan Adat Melayu Terengganu (MAIDAM).

8. Dakir, J. (2014). The existence of al-mawdū'at in the Malay community. Bangi: Universiti Kebangsaan Malaysia Publishers.

9. Yusof, M.S. (2007). Heresy: Religious and Customary Confusion. Kuala Terengganu: Terengganu Islamic Foundation.

10. Rozaimi Ramle, R. (2016). False Hadith and popular in the community. Selangor: Karya Bestari. 